\section{UDC:346.543}

DOI: https://doi.org/10.32689/26172224-2019-17-2-15-24

\section{Bogdanenko Anatoliy Ivanozych,} Ph.D. in public administration, Doctor of Science in Economics, Associate Professor of Public Administration, Interregional Academy of Personnel Management, 03039, Kyiz, Str. Frometivska, 2, tel.: (044) 26452 54, e-mail:Anatoliy_Bogdanenko@ukr.net ORCID: 0000-0003-0758-5809

\section{Богданенко Анатолій Іванович,} доктор філософіі в галузі державного управління, доктор економічних наук, доиент кафедри публічного адміністрування, Міжрегіональна Академія управління персоналом, 03039, м. Київ, вул. Фрометівська, 2, тел.: (044) 26452 54, е-таil: Anatoliy_Bogdanenko@ukr.net

ORCID: 0000-0003-0758-5809

\section{Богданенко Анатолий Иванович,} доктор философии в отрасли государственного управления, доктор экономических наук, доцент кафедры публичного администрирования, Межрегиональная Академия управления персоналом, 03039, г. Киев, ул. Фрометовская, 2, тел.: (044) 26452 54,e-mail:Anatoliy_Bogdanenko@ukr.net

ORCID: 0000-0003-0758-5809

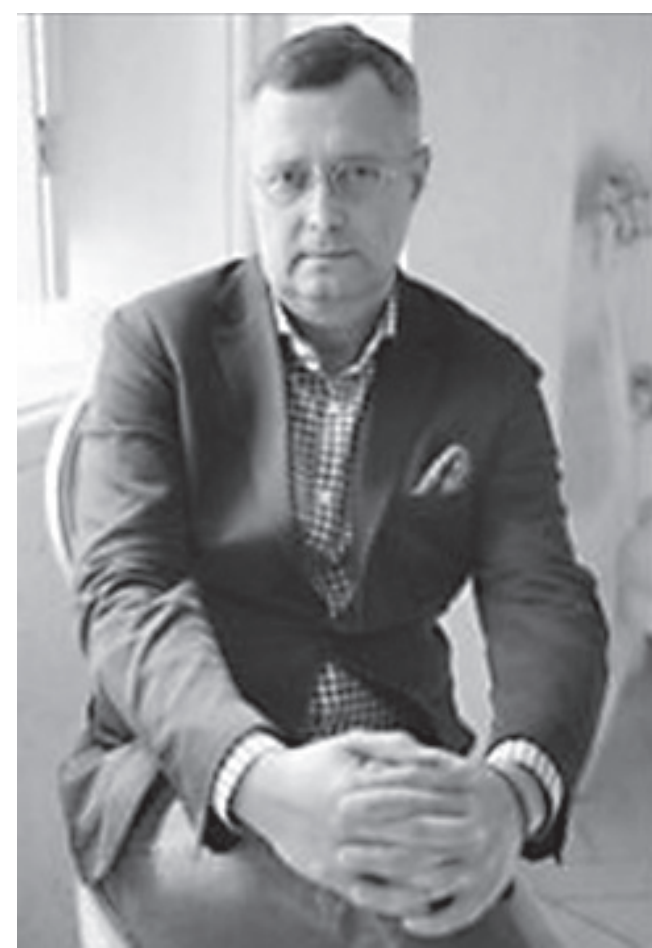

\title{
THE PUBLIC INVESTMENT POLICY IN THE SYSTEM OF FACTORS OF ECONOMIC DEVELOPMENT OF UKRAINE
}

Annotation. The essence of the state investment policy and principles of its implementation are described in the article. The state of state investment policy is investigated and measures of the state aimed at improving the implementation of effective investment policy are presented.

It is noted that the state investment policy is a series of activities of the relevant state authorities in the direction of the effective implementation of investment processes in order to ensure sustainable economic development of the country, and the main elements of which can determine the goal and objectives, the economic effect expected from its implementation, the composition of the priority areas and investment objects and principles of formation and implementation of investment policy. 
It has been determined that the main goal of the state investment policy being implemented is to attract investments in volumes that ensure the implementation of production diversification processes and an expanded economic rebuilding, and the result of an effective state investment policy is to create conditions for the transition to an investment-innovative model of economic development that is impossible without dynamic development legislation to stimulate investment. Rational investment attraction contributes to GDP growth.

It has been established that the main goal of investment management is to provide the most effective ways to implement an investment strategy and create a favorable investment climate, in the process of implementing which investment management is aimed at solving a number of critical tasks, such as ensuring high rates of economic development in the country, creating a high-tech investment complex, increasing technical level of the production apparatus, maximization of income from investment activities, minimizing investment risks, finding ways to accelerate investment programs, creating competitive export industries, ensuring financial stability in the country in the process of carrying out investment activities, positive structural changes in the economy, overcoming maladjustments, structural and technical imbalances in the economy.

It has been concluded that thanks to a well-thought-out investment policy, states can carry out the structural restructuring of the economy, increasing its level of international competitiveness and increasing export potential.

Keywords: investment policy, state investment policy, principles of investment policy.

\section{ДЕРЖАВНА ІНВЕСТИЦИЙНА ПОЛІТИКА В СИСТЕМI ФАКТОРІВ ЕКОНОМІЧНОГО РОЗВИТКУ УКРАЇНИ}

Анотація. Розкрито сутність державної інвестиційної політики та принципи її здійснення. Досліджено стан проведення інвестиційної політики держави та наведено заходи держави в напрямі покращення реалізації ефективної інвестиційної політики.

Зазначено, що державна інвестиційна політика є одним із заходів відповідних органів державної влади в напрямі ефективного здійснення інвестиційних процесів з метою забезпечення сталого економічного розвитку країни, основними елементами якої можна визначити мету і завдання політики, економічний ефект, що очікується від її реалізації, склад пріоритетних сфер і об’єктів інвестування та принципи формування та реалізації інвестиційної політики.

Визначено, що головна мета державної інвестиційної політики полягає у залученні інвестицій в обсягах, що забезпечать реалізацію процесів диверсифікації виробництва та розширеного відтворення економіки, а результатом ефективної державної інвестиційної політики є створення умов для переходу до інвестиційно-інноваційної моделі розвитку економіки, який неможливий без динамічного розвитку законодавства, для стимулю- 
вання інвестицій. Раціональне залучення інвестицій сприяє зростанню ВВП.

Встановлено, що основною метою управління інвестиційною діяльністю є забезпечення найбільш ефективних шляхів реалізації інвестиційної стратегії та створення сприятливого інвестиційного клімату, в процесі реалізації якої інвестиційне управління спрямоване на розв'язання низки найважливіших завдань, таких як забезпечення високих темпів економічного розвитку країни, створення високотехнологічного інвестиційного комплексу, підвищення технічного рівня виробничого апарату, максимізація доходів від інвестиційної діяльності, мінімізація інвестиційних ризиків, визначення шляхів прискорення інвестиційних програм, створення конкурентоспроможних експортних виробництв, забезпечення в країні фінансової стабільності в процесі здійснення інвестиційної діяльності, позитивних структурних змін в економіці, подолання диспропорцій, структурно-технічної незбалансованості економіки.

Доведено, що завдяки продуманій інвестиційній політиці держави можуть здійснювати структурну перебудову економіки, підвищуючи ㄲi piвень міжнародної конкурентоспроможності та збільшуючи експортний потенціал.

Ключові слова: інвестиційна політика, державна інвестиційна політика, принципи інвестиційної політики.

\section{ГОСУДАРСТВЕННАЯ ИНВЕСТИЦИОННАЯ ПОЛИТИКА В СИСТЕМЕ ФАКТОРОВ ЭКОНОМИЧЕСКОГО РАЗВИТИЯ УКРАИНЫ}

Аннотация. Раскрыта сущность государственной инвестиционной политики и принципы ее осуществления. Исследовано состояние проведения инвестиционной политики государства и приведены меры государства в направлении улучшения реализации эффективной инвестиционной политики.

Отмечено, что государственная инвестиционная политика является рядом мероприятий соответствующих органов государственной власти в направлении эффективного осуществления инвестиционных процессов с целью обеспечения устойчивого экономического развития страны, и основными элементами которой можно определить цель и задачи, экономический эффект, который ожидается от ее реализации, состав приоритетных сфер и объектов инвестирования и принципы формирования и реализации инвестиционной политики.

Определено, что главная цель осуществляемой государственной инвестиционной политики заключается в привлечении инвестиций в объемах, обеспечивающих реализацию процессов диверсификации производства и расширенного воссоздания экономики, а результатом эффективной государственной инвестиционной политики является создание условий для перехода к инвестиционно-инновационной модели развития экономики, который невозможен без динамического развития законодательства, для 
стимулирования инвестиций. Рациональное привлечения инвестиций способствует росту ВВП.

Установлено, что основной целью управления инвестиционной деятельностью является обеспечение наиболее эффективных путей реализации инвестиционной стратегии и создание благоприятного инвестиционного климата, в процессе реализации которой инвестиционное управление направлено на решение ряда важнейших задач, таких как обеспечение высоких темпов экономического развития страны, создание высокотехнологического инвестиционного комплекса, повышение технического уровня производственного аппарата, максимизация доходов от инвестиционной деятельности, минимизация инвестиционных рисков, нахождение путей ускорения инвестиционных программ, создание конкурентоспособных экспортных производств, обеспечение в стране финансовой стабильности в процессе осуществления инвестиционной деятельности, позитивных структурных изменений в экономике, преодоление диспропорций, структурно-технической несбалансированности экономики.

Сделан вывод, что благодаря продуманной инвестиционной политике государства могут осуществлять структурную перестройку экономики, повышая ее уровень международной конкурентоспособности и увеличивая экспортный потенциал.

Ключевые слова: инвестиционная политика, государственная инвестиционная политика, принципы инвестиционной политики.

Problem statement. The problems of investment for modern economic science and political science are the most important, since not only the state of production, socio-technical state of the economy, but the whole process of stabilization and progress of the states depends on the efficiency of the state's investment policy as a whole. The state investment policy ultimately pursues the goal of optimizing various economic interests in the course of formation and use of financial, material and other resources and is considered as a system of various measures of public authorities in order to intensify the investment activity to achieve the result (economic, social) or address the problems.
Analysis of recent research. The state investment policy is researched by many foreign and domestic scientists. Among the latter, the special mention should go to I. Blank, V. Bazylevych, A. Galchynsky, V. Mischenko, T. Mayorov, A. Peresada, V. Shevchuk, and others.

The objective of the study. The paper is aimed at definition of the essence of the state investment policy in the context of modern trends of Ukrainian economic development.

Results. For any economy, it is important to achieve macroeconomic stability, which is impossible without a clear and balanced investment policy. The essence of state investment policy is to find the ways towards expansion 
of the production potential implementation.

Thus, O. Sheverdina proposes to define investment policy as "a component of the economic policy of the state, which includes a set of legal, administrative and economic measures, is carried out in order to expand and intensify the investment processes, as well as to regulate the capital investments in order to control the restructuring of production, its technical and technological updating and modernization" [1].

According to O. Koyuda and V. Grynyova, the state investment policy is "the definition of structural and quantitative needs in investment resources, increase in the sources of financing, selection of priority areas of financing and formation of an effective proposal for attracting the investments" [2].

We believe that state investment policy is a series of measures of the relevant public authorities aimed at effective implementation of investment processes in order to ensure sustainable economic development of the country.

The main elements of state investment policy can be defined as follows:

- objective and tasks of the policy;

- economic effect expected from its implementation;

- composition of priority spheres and objects of investment;

- principles of formation and realization of investment policy [3].

According to the Law of Ukraine "On Investment Activity" [4], "the objects of investment activity may be any property, including fixed assets and working capital in all branches and sectors of the national economy, securities, special-purpose contributions, scientific-technical products, intellectual property, other objects of property, as well as property rights ... The subjects (investors and parties) of investment activity may be individuals and legal entities of Ukraine and foreign states, as well as the states".

The main objective of the implemented state investment policy is to attract investments in volumes which will ensure the realization of production diversification and expanded reproduction of the economy. Given the involvement of all subjects of market infrastructure into the investment process, the implementation of such a policy should be a catalyst for entrepreneurial activity, which will create broad opportunities for business development, creation of new and expansion of existing production facilities, and increase the filling of the state's consolidated budget with taxes.

Taking into account the tasks of the state investment policy, it is possible to form a system of principles, the observance of which contributes to the formation of an effective state investment policy, which should be divided into the general principles to be followed in developing the main areas of such policy, and the principles to be followed in assessing its implementation. The general principles of state policy in the investment area should be as follows [3]:

- practical need to achieve the goal and its scientific validity;

- set goals should be transparent, understandable and desirable for the population as well as for groups with special economic interests;

- any objective of state regulation of the economy can be set and achieved 
only in conjunction with all other goals according to its place in the system of priorities of objectives;

- creation of an effective coordination mechanism and close cooperation between the parties to the implementation of the policy;

- substantiality, consistency, publicity and predictability of the state investment policy;

- priority of state support of the sectors strategically important for the state, which ensure the functioning of the whole national economy, innovation breakthrough, development of social infrastructure, and ecological safety;

- rejection of the practice of excessive interference into the operation of the market sector, stimulation of the attraction of private capital to solve the key tasks of socio-economic development of the country.

The principles to be followed when evaluating the state investment policy implementation are as follows:

- principle of investment process decentralization - all investment processes which can be carried out without the obligatory participation of the state as a partner shall be transferred for implementation to private companies and individuals, to create all prerequisites for this and provide certain state guarantees, if necessary;

- principle of controllability - the constant control over the use of public funds and funds of local budgets allocated as part of the complementary investment policy of the state for the realization of the necessary projects;

- principle of adaptability - constant correction of tactical measures of the state's investment policy due to the economic development of society. Stra- tegic benchmarks of mentioned policy should remain stable, since the permanent changes in legislation do not contribute to improving the country's investment climate;

- principle of effectiveness - continuous monitoring of the state's investment policy efficiency and correction of measures in case of ineffective implementation of the mentioned program and failure to receive the expected effects of its implementation;

- principle of continuity - process of improving the investment policy of the state is endless, and upon completion of the stage of achieving the stated goals it is required to develop new directions of the country's investment climate improvement;

- principle of interaction harmonization in the course of implementation of the state's investment policy, an important role is played by the interaction between the public authorities and local self-government.

The result of an effective state investment policy is creation of the conditions for the transition to an investment-innovation model of economic development, which is impossible without the dynamic development of legislation, and stimulation of investments. The rational attraction of the investments promotes the GDP growth.

Currently, the investment sphere of our country is characterized by insufficient financing of the country's economy, except for several branches, mainly connected with the export of raw materials and energy resources. The real sector of the economy suffers from chronic lack of investments.

This is precisely why the state investment policy should become one 
of the priorities in functioning of the country's economy, ensuring its sustainable development.

The main purpose of investment activity management is to provide the most effective ways towards the implementation of investment strategy and creation of favorable investment climate. In the course of realization of this main goal, the investment management is aimed at solving the following important tasks [5]:

- ensuring high rates of economic development of the country through effective investment activity;

- creation of high-tech investment complex able to meet the needs of the economy in investment products and services of decent quality;

- raising the technological sophistication of the productive facilities;

- maximization of income from investment activity;

- minimization of investment risks;

- finding the ways to accelerate the investment programs;

- creation of competitive export production, which will ensure the effective foreign economic relations of Ukraine;

- ensuring of financial stability in the country in the course of the investment activities, positive structural changes in the economy, overcoming of disproportions, structural and technical imbalances of the economy.

Activation of attraction of investments into priority areas of operation shall be carried out by means of certain instruments - investment, financialcredit, tax leverages in proportion to the strategic goals of Ukraine's development. The effectiveness of these instruments can be measured by analysis of the dynamics and structure of investing in the national economy in the context of implementation of the strategic goals of its development.

According to the Strategy for Sustainable Development "Ukraine-2020", "in order to support the investment activity and protect the rights of investors, it is necessary to ensure effective protection of the right to private property, including protection by the judicial authorities, to harmonize with the legislation of the European Union the provisions of the Ukrainian legislation on the protection of the rights of domestic and foreign investors and creditors, protection of economic competition, to introduce the incentive mechanisms of investment activity based on the best world practice" [6].

The main indicators of investment activity are, first of all, the positive growth rates both in general and in categories (private and foreign investments); increase in the number of investment projects as a whole, as well as in certain industries and territories; an increase in the share or scope of inclusion into a business turnover of a particular type of resources.

Among the weaknesses in the implementation of the state investment policy, the following should be stated: unstable political situation which is a prerequisite for attracting the investments into the country, the lack of incentive legislation in the investment and tax sector, in the area of publicprivate partnership, low level of capitalization of enterprises, which reduces their financial and investment opportunities, high degree of dependence of the state budget on transfers, the low level of professional competence 
(lack of highly-qualified personnel), etc. [7].

However, at present, the state takes certain measures aimed at improving the investment policy. Thus, according to the report of the Ministry of Economic Development and Trade, the steps were taken in 2016 towards the stable development of the Ukrainian economy and intensification of investment activity, namely:

- protection of investors' rights measures are taken to join Ukraine in the OECD Declaration on International Investments and Multinational Enterprises;

- development of public-private partnership - improved procedure for calculation of the concession payments, introduced international practice of preparing the public-private partnership projects in identifying the mechanisms for fair distribution of risks between the intergovernmental and private partners, simplified procedure for providing the state partner by private partner with the information on the implementation of the contract entered into as part of public-private partnership, more effective mechanisms for cooperation between the state and the territorial communities (state partners) and private partners as part of public-private partnership are created, work on reforming of the Ukrainian concession legislation commenced;

- concerning the improvement of the state (capital investment) investment management system - approved new transparent procedures for project selection, composition of the Interdepartmental Commission, as well as a list of requirements set for state investment projects;
- development of investment infrastructure - work on the implementation of the Law of Ukraine "On Industrial Parks" stipulating the state support for the development of industrial parks [8] continues.

The country's investment climate may be improved by various measures, including ensuring a clear legal framework for investment activity, macroeconomic and political stability, introduction of tax and customs privileges, grants, subsidies, subventions and budget loans for the development of priority sectors of the economy, overcoming the bureaucratic barriers, corruption, ensuring a legal protection of investments, improvement of information support and investment infrastructure.

In terms of strategic contents and practical execution, the policy of regulating the foreign direct investment inflows in Ukraine should effectively coordinate the complex combination of the interests of foreign and national investors. The officially recognized forms of support for the national economy and national private business are less risky for the economy, as they are subject to control by the public and expert professional organizations than the "manual" regulation which is completely in the shade [9].

In order to attract new investors, the policy and institutional principles of support for investments require consolidation. A more detailed strategy and action plan are necessary to achieve the result. After the liquidation of the State Agency for Investments and National Project Management, more attention should be paid to the state support of foreign and domestic investors through the provision of business services and 
information support. The state should consider the launching of a structure responsible for the investment promotion with clear functions and appropriate funding. Creation of a user-friendly and regularly updated on-line portal developed specifically for potential and already operating investors in the country would help investors to get information and raise their awareness about the recent legislative and regulatory amendments and future opportunities.

Conclusion and prospects for further research. Thus, due to well thought-out investment policy, the states can implement the restructuring of the economy, enhancing its international competitiveness by increasing the export potential.

However, it is important that the instrumental content of the investment policy is not only declared as possible for use, but is actually applied at the macro and meso-economic levels in the context of the sectors and territories identified by the strategic priorities of the state economic policy.

The state's investment policy should be first and foremost balanced and effective. The study we have conducted indicates that currently the state takes some steps aimed at improving and perfection of the investment climate in Ukraine, but they are not sufficient for stable economic development. At present, the investment policy development receives new opportunities which should be adapted to the chosen European integration course of foreign policy.

\section{REFERENCES}

1. Sheverdina O. V. (2012), "Investment Policy of Ukraine as an Object of State
Economic Policy", Publichne upravlinnia: teoriia ta praktyka, vol. 4 (12), p. 111-117.

2. Koiuda O. P., Lepejko O. P., Koiuda V. O, Hryn'ova V. M. (2008), "Investment", Znannia, p. 452.

3. Kviatkovs'ka L.A., Talover V. A. (2016), "Structural elements of the formation of state investment policy", Naukovyi visnyk Khersonskoho derzhavnoho universytetu. Economic sciences, vol. 17 (1), p. 46-50.

4. The Verkhovna Rada of Ukraine (2017), The Law of Ukraine "On Investment Activity”, available at: http://zakon2.rada.gov.ua/laws/ show/1560-12/page (Accessed 11 April 2018).

5. Pshenychna V. P. (2010), "Features of the formation and development of the mechanism of realization of the state investment policy in Ukraine", Ekonomika ta derzhava,vol. 6, p. 59-61.

6. The Verkhovna Rada of Ukraine (2017), the Decree of the President of Ukraine "On the Strategy of Sustainable Development Ukraine 2020", available at: http://zakon.rada.gov.ua/ laws/show/5/2015 (Accessed 11 April 2018).

7. Hotsuliak L. (2016), "State investment policy: goals and objectives in the context of the formation of an innovative economy", Economist, vol. 8, p. 33-36.

8. Ministry of Economic Development and Trade of Ukraine (2016), "Information and analytical materials on the investment climate in Ukraine for 2016", available at: http://www. me.gov.ua/Documents/List?lang $=$ ukUA \& t a g $=\%$ D $0 \%$ A $1 \%$ D $1 \%$ $82 \%$ D0\%B0\%D0\%BD\%20\%D1\%9 $6 \% \mathrm{D} 0 \% \mathrm{BD} \% \mathrm{D} 0 \% \mathrm{~B} 2 \% \mathrm{D} 0 \% \mathrm{~B} 5 \% \mathrm{D}$ $1 \% 81 \% \mathrm{D} 1 \% 82 \% \mathrm{D} 0 \% \mathrm{~B} 8 \% \mathrm{D} 1 \% 86$ \% D1\%96\%D0\%B9\%D0\%BD\%D0 \%BE\%D1\%97\%20\%D0\%B4\%D1\% $96 \% \mathrm{D} 1 \% 8 \mathrm{~F} \% \mathrm{D} 0 \% \mathrm{BB} \% \mathrm{D} 1 \% 8 \mathrm{C} \%$ D0\%BD\%D0\%BE\%D1\%81\%D1\%- 
$82 \% \mathrm{D} 1 \% 96 \% 20 \% \mathrm{D} 0 \% \mathrm{~B} 2 \% 20 \% \mathrm{D} 0 \%$ A3\%D0\%BA\%D1\%80\%D0\%B0\%D1 $\% 97 \% \mathrm{D} 0 \% \mathrm{BD} \% \mathrm{D} 1 \% 96$ (Accessed 11 April 2018).

9. Frolova H. I. (2014), "Estimation of the investment climate in Ukraine", Visnyk Berdianskoho universytetu menedzhmentu i biznesu, vol. 2, p. $67-69$.

\section{СПИСОК ВИКОРИСТАНИХ ДЖЕРЕЛ}

1. Шевердіна О. В. Інвестиційна політика України як об’єкт державної економічної політики / О.В.Шевердіна // Публічне управління: теорія та практика. - 2012. - № 4 (12). - C. 111-117.

2. Коюда О. П. Інвестування / О. П. Коюда, О. П. Лепейко, В. О. Коюда та ін. - К.: Знання, 2008. $452 \mathrm{c}$.

3. Квятковська Л. А. Структурні елементи формування державної інвестиційної політики [Електронний ресурс] / Л. А. Квятковська, В. А. Таловер // Наук. вісн. Херсонського держ. ун-ту. Сер. : Економічні науки. - 2016. - Вип. 17 (1). - С. 46-50.

4. Закон України "Про інвестиційну діяльність” // Відомості Верховної Ради України від 18.09.1991, № 47 (зі змін. та доповн. від 23.07.2017, підстава 2095-19) [Електронний pecypc]. - Режим доступу: http:// zakon2.rada.gov.ua/laws/show/156012 /page
5. Пшенична В. П. Особливості формування та розвитку механізму реалізації державної інвестиційної політики в Україні / В. П. Пшенична // Економіка та держава. - 2010. № 6. - С. 59-61.

6. Указ Президента України "Про Стратегію сталого розвитку Україна-2020” // Президент України; Указ, Стратегія від 12.01.2015 № 5/2015.

7. Гоцуляк Л. Державна інвестиційна політика: цілі та завдання в умовах формування інноваційної економіки [Електронний ресурс] / Л. Гоцуляк // Економіст. - 2016. - № 8. C. 33-36.

8. Інформаційно-аналітичні матеріали щодо інвестиційного клімату в Україні за 2016 рік [Електронний ресурс]. - Режим доступу: http://www. me.gov.ua/Documents/List?lang=uk$\mathrm{U} A \& \mathrm{t}$ a $\mathrm{g}=\%$ D $0 \%$ A $1 \%$ D $1 \%$ $82 \%$ D0\%B0\%D0\%BD\%20\%D1\%9 $6 \% \mathrm{D} 0 \% \mathrm{BD} \% \mathrm{D} 0 \% \mathrm{~B} 2 \% \mathrm{D} 0 \% \mathrm{~B} 5 \% \mathrm{D}$ $1 \% 81 \% \mathrm{D} 1 \% 82 \% \mathrm{D} 0 \% \mathrm{~B} 8 \% \mathrm{D} 1 \% 86$ $\%$ D $1 \% 96 \%$ D0\%B9\%D0\%BD\%D0 $\% \mathrm{BE} \% \mathrm{D} 1 \% 97 \% 20 \% \mathrm{D} 0 \% \mathrm{~B} 4 \% \mathrm{D} 1 \%$ $96 \%$ D $1 \% 8$ F\% D0\%BB\%D 1\%8C\% D0\%BD\%D0\%BE\%D1\%81\%D1\%$82 \% \mathrm{D} 1 \% 96 \% 20 \% \mathrm{D} 0 \% \mathrm{~B} 2 \% 20 \% \mathrm{D} 0 \%$ A3\%D0\%BA\%D1\%80\%D0\%B0\%D1 $\% 97 \% \mathrm{D} 0 \% \mathrm{BD} \% \mathrm{D} 1 \% 96$

9. Фролова Г. І. Оцінка інвестиційного клімату в Україні [Електронний ресурс] / Г. І. Фролова // Вісн. Бердянського ун-ту менеджменту і бізнесу. - 2014. - № 2. - С. 67-69. 